\title{
Such Books Should be Burned! Same-Sex Parenting and the Stretchable Definition of the Family in Larysa Denysenko's and Mariia Foya's Maya and Her Mums
}

\section{Mateusz Świetlicki ${ }^{1}$ (])}

Published online: 19 October 2019

(c) The Author(s) 2019

\begin{abstract}
As there is a myriad of Anglophone picturebooks featuring same-sex parents, some Western readers familiar with them would probably see little that is ground-breaking in the visual and verbal narrative of Larysa Denysenko's and Mariia Foya's Maya and Her Mums (2017). The picturebook's first-person narrator and protagonist is a ten-year-old girl who describes her 16 classmates and their families; it includes no violence, no nudity, and no sexual references. Despite the title suggesting the story to be about the eponymous heroine and her family, Maya briefly introduces readers to her two mothers in one of the last doublespreads. When Maya and Her Mums was included in the programme of Ukraine's most important book fair, the Lviv Book Forum, it became a political tool in the confrontation between homophobic Ukrainian nationalists and progressive intellectuals. In this essay, I want to examine the depiction of same-sex parenting in Maya and Her Mums and argue that it implies gradual widening of tolerance, with households headed by lesbian parents being the most controversial. Thus, the picturebook suggests that the definition of the family is stretchable, even in a conservative socio-political climate. By familiarising readers with Denysenko's and Foya's picturebook, I want to show what makes it different from equivalent Anglophone picturebooks and argue that the Ukrainian book market is slowly becoming more inclusive and diverse. Hence, despite the conservative
\end{abstract}

\footnotetext{
Mateusz Świetlicki is an Assistant Professor at the Institute of English Studies, University of Wrocław. He is a founding member of the Centre for Research on Children's and Young Adult Literature (Faculty of Letters, University of Wrocław). He was a Fulbright scholar at the University of Illinois at Chicago (2018). He was also awarded fellowships at Taras Shevchenko National University of Kyiv (2014) and Harvard University (2012). His first book, When (Do) Boys Become Men? Masculinity as a Project in Serhiy Zhadan's Fiction (Kiedy chtopcy zostaja mężczyznami? Męskość jako projekt w prozie Serhija Żadana), was published in 2016. He specializes in North American and Ukrainian studies. His expertise is contemporary children's and YA literature and culture, as well as popular culture and film. He has taught literature, film, and popular culture at the University of Wrocław and the University of Illinois at Chicago. He is currently working on a project on memory in children's literature. He is a representative for the Childhood \& Youth Network of the Social Science History Association.
}

Extended author information available on the last page of the article 
backlash, the need for for same-sex parents and their children to be represented in children's literature can no longer be ignored.

Keywords Same-sex parenting · Picturebook · Queer · Ukrainian children's literature

Until September 2017, Majja ta i'i' mamy (Maya and Her Mums), the first Ukrainian picturebook about family diversity featuring same-sex parenting, was known only to a limited number of young readers and their progressive parents and teachers. Written by author and journalist Larysa Denysenko and illustrated by Mariia Foya, ${ }^{1}$ it was initially met with critical acclaim and positive responses from readers. In her online review, fellow author Oksana Lushchevska seems to reference Rudine Sims Bishop's seminal 1990 article Mirrors, Windows, and Sliding Glass Doors when she argues that the book "may become a mirror, a window, a door [...] showing something new, inviting the reader to enter the world of otherness and diversity" (Lushchevska, 2017). The first edition, released by niche publisher Vydavnytstvo in Spring 2017, was funded by the Heinrich Böll Foundation, which is "part of the Green political movement" that focuses on promoting "social emancipation," "equal rights for women and men," "equal rights for cultural and ethnic minorities," and "the societal and political participation of immigrants" (Boell, 2008). The picturebook was first presented in Kyiv and proved to be quite successful—by September 2017 it had to be reprinted for the second time, as the first two limited editions sold out. When it was included in the programme of Ukraine's most important book fair, the Lviv Book Forum, Maya and Her Mums turned out to be more than a children's book-it became a political tool in the confrontation between homophobic Ukrainian nationalists and progressive intellectuals.

In this essay, I want to analyse Maya and Her Mums and show that while the title focuses only on the eponymous heroine's family, the picturebook cleverly becomes an encyclopaedia of families, as Denysenko and Foya gradually familiarise readers with certain taboos before addressing same-sex parenting, seen as the most controversial topic. Hence, what makes this picturebook radical is that it suggests a gradual widening of tolerance and shows that the definition of the family is stretchable. This article is a reflection of some theoretical examinations about what makes a contemporary picturebook queer, particularly in a cultural context where the merest mention of lesbian mothers is seen as radical. As Jane Sunderland and Mark McGlashan (2010, p. 190) rightly argue, books about same-sex parents not only encourage acceptance but also give children raised in such families reading material. Even though for some Western readers familiar with many Anglophone picturebooks about same-sex parents-as well as the increasingly more popular ones featuring queer children-Maya and Her Mums may seem quite conservative, I would like to argue that in Ukraine, a country struggling with deeply-rooted homophobia

\footnotetext{
1 The first two editions only feature Denysenko's name on the cover. The third one acknowledges Foya as Denysenko's co-creator.
} 
(Martsenyuk, 2012), the appearance of such a book is significant and worth exploring, as it is the first one promoting diversity and providing children living in households headed by same-sex parents with literary representation.

\section{Maya and Her Mums_Is It a Queer Picturebook?}

Until the last few decades, children's literature featured characters assumed to be heterosexual and cisgender only. As Tison Pugh (2011, p. 1) notes, most children's books indirectly or openly promote heteronormativity through the presence of heterosexuality as the sexual identity of a vast majority of characters and their families. Similarly, Steven Bruhm and Natasha Hurley (2004, p. ix) claim that according to the dominant discourse "children are (and should stay) innocent of sexual desires and intentions. At the same time, however, children are also officially, tacitly, assumed to be heterosexual." However, children are not-yet-straight because they are at the same time supposed to be nonsexual (Stockton, 2004, p. 7). This situation is contradictory, as James Kincaid (1998, p. 55) notes:

[T]he idea of innocence and the idea of "the child" became dominated by sexuality - negative sexuality, of course, but sexuality all the same. Innocence was fled down to mean little more than virginity coupled with ignorance; the child was, therefore, that which was innocent: the species incapable of practicing or inciting sex. The irony is not hard to miss: defining something entirely as a negation brings irresistibly before us that which we're trying to banish.

As children's books are written mostly by adults for non-adult readers, children's literature and its critical response are defined not only by the needs of children, but mostly by the attitudes and beliefs of adults. Karín Lesnik-Oberstein (1994, p. 9) even argues that "[f]or the purpose of children's literature criticism, so closely involved with children's supposed emotions and states of mind... the 'child' is a construction, constructed and described in different, often clashing, terms." Thus, the assumed innocence of children protects not only children but also adults (Pugh, 2011, p. 4). Children's literature plays an important political role as the child represents the future, and the idea that innocence cannot last forever. Queer theorist Lee Edelman claim that "the image of the Child, not to be confused with the lived experience of any historical children, serves to regulate political discourse" (2004, p. 11). Consequently, the Child is a political tool, and as Edelman argues "the cult of the child ... permits no shrines to the queerness of boys and girls, since queerness, for contemporary culture at large ... is understood as bringing children and childhood to an end." (2004, p. 19). In this thought-provoking book Edelman argues that queer theory should reject the notion of "the Child as futurity's emblem" (2004, p. 30).

This leads me to a fundamental question-can children's books such as Maya and Her Mums be called queer? Is there a difference between a book about queerness and a queer book? The answers to either question are not clear. Reclaiming the term queer in the 1990s gave voice to those previously seen as outlaws - first in the Anglophone world, then the word queer spread all around the world and is now also 
used in the former Eastern Bloc. As Tison Pugh observes, children's literature is supposed to "preserve children's innocence" but at the same time portrays "heterosexuality as childhood's desired end"-this contradictory situation shows "the queer foundations of children's literature." (2011, p. 2). Using the term queer makes it possible to re-examine children's otherness by questioning the binary divisions between children and adults, who protect the general idea of innocence. ${ }^{2}$ Additionally, when we consider David Halperin's seminal understanding of queerness as something that can be referred to "whatever is at odds with the normal, the legitimate, the dominant... [and] is not restricted to lesbians and gay men" (1995, p. 62), or Caroline Gonda's words that "anyone who feels at odds with social or sexual convention can claim the label 'queer"' (Gonda in Jackson and Jones, 1998, p. 124), in the Ukrainian context Maya and Her Mums may be considered a picturebook about queerness. Still, as all of the young characters are cisgender and assumed to be heterosexual, and no intimacy between the protagonist's lesbian mothers is shown in either the verbal or the visual narrative, calling it a queer picturebook in the Western understanding of this term is more problematic, especially when we compare it to what Jennifer Miller calls “new queer children's literature” (2018, p. 1)—picturebooks with openly queer children, often autobiographical or written by the parents, like Christine Baldacchino's Morris Micklewhite and the Tangerine Dress (2014) or I Am Jazz (2014) by Jessica Herthel and Jazz Jennings.

\section{The Controversy-Maya and Her Mums as 'a Propaganda Tool'}

In Ukraine, just as in Western society, children and children's literature have traditionally been depicted as innocent and non-sexual (Kachak, 2016). Thus, the short mention of a family headed by a same-sex couple in Maya and Her Mums, a picturebook for primary school children, written in Ukrainian by a straight author, was enough for the right-wing critics to call it a "nail in the coffin of the Ukrainian family" (Zhuravel, 2017). In early September 2017, the organizers of the Lviv Book Forum received a letter from 15 conservative organizations, such as the ultranationalist Right Sector, pressing them to cancel the presentation of Maya and Her Mums scheduled for September 15, 2017. Representatives of The National Corps Party of the Lviv Region claimed that the book is "a tool of ... propaganda that not only destroys the essence of art, but also transforms it into a mechanism for the destruction of moral and universal values" (Wesolowsky,

\footnotetext{
${ }^{2}$ In Over the Rainbow: Queer Children's and Young Adult Literature (2011) Michelle Ann Abate and Kenneth Kidd present the history of the usage of the term "queer" in relation to children and literature. They mention that numerous children's books published in the late nineteenth and early twentieth centuries use "queer" as a synonym for the strange, aristocratic, and fantastic: for instance, Edward Eggleston's Queer Stories for Boys and Girls (1884), E.H. Knatchbull-Hugessen's Queer Folk: Seven Stories (1874), Harriet Beecher Stowe's Queer Little People (1867), and Palmer Cox's Queer People with Wings and Stings and Their Kweer Kapers (1895). Ann Abate and Kidd (2011, p. 4) also observe that in many classic texts, such as Frances Hodgson Burnett's The Secret Garden (1911), children who are significantly different from the others are labelled "queer".
} 
2017). The publisher responded to the accusations by saying: "this is the first time in the history of Ukrainian literature that a children's book and its author have been threatened along with the publisher." (Wesolowsky, 2017). Despite the backlash, Denysenko and Foya received support from politicians, such as Ivanna Klympush-Tsintsadze and Svitlana Zalishchuk, as well as other influential figures, for instance, Myroslava Gongadze, a political activist fighting for freedom of speech, whose husband, journalist Georgiy Gongadze, was brutally murdered in 2000. Eventually, the scheduled presentation in the children's library was cancelled, but the book was included in two other events-a workshop on female writers and a discussion on the importance of talking about difficult topics with pupils in classrooms (ZIK, 2017 September 14). As a result of the unexpected publicity, the picturebook received national and international press coverage (Morgan, 2017, September 15). Some commentators even believed the controversy to be a promotional stunt (ZIK, 2017 September 14), but Vydavnytstvo denied the claims and decided to distribute a pdf edition of the book for free, making the book widely available.

While both advocates and opponents of the picturebook seemed convinced about the power of early literacy, it is worth mentioning that the dispute surrounding Maya and Her Mums at the Lviv Book Forum was not the first ideological clash over a Ukrainian book between right-wing nationalists and liberal intellectuals. When 120 Storinok Sodomu (120 Pages of Sodom), edited by Iryna Shuvalova, Al'bina Pozdnjakova, and Oles' Barlih, and known as "the milestone of Ukrainian queer culture-building" (Chernetsky, 2016, p. 216) was published in 2009, it was met with violent protests and numerous acts of vandalism. As Vitaly Chernetsky notes, during the September 10 presentation of the anthology in Lviv, the presenters were physically attacked by a group of young, homophobic men who smashed windows, demolished microphones, destroyed books, and attacked the editors and translators of the volume with tomatoes and mayonnaise (Chernetsky, 2016, p. 217). The Ukrainian Police did not want to intervene. The next presentations in Lviv and Kyiv were met with a similar response from the right-wing attackers, including representatives of the extreme-right political party Svoboda (Freedom).

What makes Maya and Her Mums and 120 Pages of Sodom similar? The discrepancy between the content and the provocative title. The latter is a volume of about 150 pages of poetry and prose by selected authors from the US and Europe in Ukrainian translations, an introductory essay by well-known poet and translator Andrii Bondar and a scholarly afterword by Marija Majerchyk. The violent response was caused by the fact that it is the first post-Soviet anthology of works by LGBTQ+ writers published in the former USSR, daringly titled after Marquis de Sade's notorious The 120 Days of Sodom. In both cases, the titles provoked unprecedented media attention. Consequently, instead of further marginalization, queer authors and the theme of same-sex parenting gained visibility. While Maya and Her Mums' title seems to recall Lesléa Newman's Heather Has Two Mommies (1989), one of the first popular Anglophone children's books about same-sex parenting, which has never been translated into Ukrainian, it is focused on depicting broadly understood nontraditional family models. 


\section{Maya and Her Mums as an Encyclopaedia of Non-traditional Family Models}

That fact that Maya and Her Mums is a picturebook makes it problematic in the context of the aforementioned Ukrainian ideological dilemma as pictures can be seen as a way of challenging or evading censorship. As Perry Nodelman observes, picturebooks "imply a viewer who is innocent, unsophisticated-childlike" and they "combine the childlike and the sophisticated" as "the viewer they imply is both very learned and very ingenuous" (1998, p. 21). Nikolajeva and Scott also argue that the distinctive role of picturebooks "is based on a combination of two levels of communication, the visual and the verbal" (2000, p. 1). Unlike verbal-only narratives, picturebooks help children acquire multimodal literacy. Consequently, such books play an important educational and ideological role as they produce multiliterate individuals (Arizpe and Style, 2003; Lewis, 2001). Apart from the development of critical and visual thinking, picturebooks allow parents and teachers to familiarize young readers with difficult issues in a safe environment. Unsurprisingly, the first Ukrainian books for children about the Euromaidan revolution, death, and the war in Donbas were picturebooks (Świetlicki, 2018). Probably due to the political situation in Ukraine also, one of Maya's classmates is a refugee and another lost her father in Donbas. Nikolajeva argues that "Children have limited life experience of emotions; therefore, fiction can offer vicarious emotional experience that children can partake of in a safe mode, without risking fatal mistakes or even small embarrassment" (2014, p. 121). Reading picturebooks can have a therapeutic function as it leads to interactions between adults and children, often allowing them to start discussing difficult matters, such as war, death, and sexuality-all appearing in Maya and Her Mums, with the latter seen as the most problematic.

The possible therapeutic function of Maya and Her Mums is strengthened by the first-person narrative and the two complementary voices - the pictures add a different meaning to the text and make it more challenging, especially when it comes to the representation of the protagonist's lesbian mothers. It is narrated by Maya, a confident and reasonable ten-year-old girl who likes summer, watermelons, and W.I.T.C.H. dolls, all appearing in the first doublespread. Maya is not a passive narrator; she is inquisitive, and asks readers numerous questions, such as "what do you like?", "do you have any secrets?" (p. 24), "how many words do you know in English? Italian? Russian?" (p. 34). In the first doublespread, we can see Maya's right hand writing on a tablet. This may suggest that the visual narrative is also a first-person one. The eponymous heroine always starts with explaining the peculiarity of the background of her friends' families and then provides readers with more detailed information. Interestingly, not every child can be found in the visual narrative; sometimes Maya only describes her classmates and the illustrations focus on objects she associates with them. Foya uses mostly calm, pastel colours mixed with brighter ones related to each child's background. Although Maya frequently mentions her classmates' parents, everything she knows about 
them comes from their children. Consequently, they rarely appear in full, as Foya portrays their hands, silhouettes, and fragments of photographs.

While all classmates come from households often treated in Ukraine as non-traditional (e.g., single parents; blended families; foster homes), all of the parents and children in the book are assumed to be heterosexual, except for Maya's two mothers. Before introducing her own family, apparently the most unusual one for most Ukrainian children, yet one that readers probably expect to meet early on because of the suggestive title, Maya gradually familiarizes the audience with other forms of diversity. This may help the readers to first identify with some of the characters, for example children of economic migrants, refugees, divorced parents or conceived through in vitro fertilization (IVF). Moreover, before being introduced to Maya's family they already know that the eponymous heroine is in love with a boy, they learn what IVF is, and realize that some children are raised by two women (e.g., mothers and grandmothers). Denysenko and Foya progressively accustom readers to these issues by introducing Sofiyka, Solomiya, Danylko, Nazar, and Nastia first, instead of just focusing on Maya and her lesbian mothers. Sofiyka the First (there are two other girls named Sofiyka in her class) is Maya's best friend, and has a twin sister called Solomiya. Unlike other children in the class, the girls were conceived through IVF. As they are called names such as "artificial children," the teacher, Ms Julia, explains to her pupils that all children are equal. Maya clarifies what artificial insemination is and, remarkably, highlights the importance of the anonymity of the sperm donor. While the issue of IVF is still controversial in Ukraine, in the doublespread featuring the twins, a doctor is depicted as a flying superhero, as medicine made it possible for their parents to have children. The presence of Sofiyka and Solomiya, children of heterosexual parents, makes it easier for the readers to later accept the fact that Maya's biological father was also a secret sperm donor.

Another significant character is Danylko, who lives with his single mother and does not know his father. While Maya describes his mother, the children's swimming coach, as funny, strong, independent, and beautiful, in one of the illustrations we can only see her hand in the swimming pool. Although Danylko is raised by his single mother and Maya has two mothers, both children are assumed to be heterosexual. The protagonist even tells readers her biggest secret-she is in love with Danylko and wants to send him a Valentine's Day card. The fact that Maya is stereotypically girly and is in love with a boy seems significant in the context of the Ukrainian attitudes to the adoption of children by same-sex parents, as most Ukrainians are against it as they believe that such children would grow up to be homosexual (Martsenyuk, 2012). While Maya's mothers are the only same-sex parents in the book, their household is not the only one headed by women. Maya's close friend Nastia is raised together with her first cousin Nazar by their single mothers- the women are sisters-and grandmother. The doublespread that introduces them shows a rolling pin and ingredients necessary for baking a cake, symbolizing the feminine character of the household. Whereas the children do not look alike, they are like siblings and have a room painted in soft, gender-neutral colours.

Even though Maya is the first-person narrator and the first child the readers get to know, she coyly introduces her mothers last, right after the families of Raiis, who is a Crimean Tatar refugee, and Petro, who is Romani. Hence, there is an odd 
cognitive dissonance in the fact that the title immediately introduces readers to the mothers, yet they get introduced to them last. The title is a way of making Maya and Her Mums more immediately radical, even though it operates, in fact, on a much more progressive and careful level. Despite the title suggesting the story to be about Maya and her mums, the girl is the only one appearing on the cover of the book, and there is only one illustration of Maya's two mothers inside the book. ${ }^{3}$ The final doublespread depicts the three of them holding hands and flying above a colourful city. "I have two mothers. People are often surprised-how is that possible? [...] my mothers are not a secret, they are very real. They love one another and they love me." - this, apart from the title, is the only sentence in the entire book about Maya's mothers. There is no verbal reference to physical contact between the women; in the visual representation they are both holding Maya's hand but looking at each other. While the lack of direct physical contact suggesting homosexuality is typical of picturebooks about same-sex parents (Sunderland and McGlashan, 2010, p. 199), flying in Maya and Her Mums may symbolize freedom and wish fulfilment, as well as an attempt to escape prejudice. Both of Maya's mums look cisgender-one has long, red hair and is wearing a green and red blouse and black trousers; the other, presumably the biological mother, has black, shoulder-length hair and is dressed in a striped shirt and a long, red skirt. Interestingly, such visual representation defies the stereotypically negative depiction of lesbians in the post-Soviet media (Baer, 2011; Stella, 2015). On one of the last pages, Maya repeats her teacher's positive words that all children are equal and it does not matter what type of family they have as long as they respect and love one another-the doublespread depicting Maya's family shows that, just like all of her classmates, she seems happy and loved. From a narrative perspective, Maya and Her Mums suggests that readers can progressively grow to accept otherness, all the way from IVF and single parenthood, through refugees and racial minorities, to the most controversial one-LBGTQ parents. Thus, it symbolises the order in which non-traditional families in Ukraine gain social acceptance, and, at the same time, marks same-sex parenting as the most controversial.

\section{Conclusion}

In the Anglophone world, books about same-sex parents such as Heather Has Two Mommies or Michael Willhoite's Daddy's Roommate (1990) no longer seem that radical (Chick, 2008), especially when compared to the "new queer children's literature." While Denysenko and Foya provide readers with quite a conservative narrative with no queer children, and focus on showing that Maya's lesbian mothers managed to raise a girly daughter who is in love with a boy, as the sexuality of the parents does not have to define their children, it caused a heated debate in homophobic Ukraine, with the right-wing critics accusing the book of destroying the Ukrainian family. Unlike similar Anglophone picturebooks, focused on same-sex parenting only, Maya and Her Mums gives literary visibility to the countless children raised in

\footnotetext{
${ }^{3}$ While the back cover includes a vignette of two holding hands, they are the hands of children.
} 
various types of families, not only households headed by LGBTQ+ couples. While it is difficult to call it a queer book, as it features exclusively cisgender children assumed to be heterosexual, it gives hope that the Ukrainian book market is slowly moving towards depicting more inclusivity and diversity. Because of Maya and Her Mums, Ukrainian same-sex parents and their children finally found literary representation, and one may hope that unequivocally queer books, giving similar visibility to children who are not cisgender or assumed to be heterosexual will eventually follow.

Open Access This article is distributed under the terms of the Creative Commons Attribution 4.0 International License (http://creativecommons.org/licenses/by/4.0/), which permits unrestricted use, distribution, and reproduction in any medium, provided you give appropriate credit to the original author(s) and the source, provide a link to the Creative Commons license, and indicate if changes were made.

\section{References}

Abate, Michelle Ann, and Kidd, Kenneth. (2011). Over the Rainbow: Queer Children's and Young Adult Literature. Ann Arbor: The University of Michigan Press.

Arizpe, Evelyn, and Style, Morag. (2003). Children Reading Pictures: Interpreting Visual Texts. London: Routledge.

Baer, Brian James. (2011). Body or Soul: Representing Lesbians in Post-Soviet Russian Culture. Journal of Lesbian Studies, 15(3), 284-298.

Boell. (2008, 11 March). The Heinrich Böll Foundation-Mission Statement. Accessed May 10, 2019, from https://www.boell.de/en/foundation/about-us-2188.html.

Bruhm, Steven, and Hurley, Natasha (Eds.). (2004). Curiouser: On the Queerness of Children. Minneapolis: University of Minnesota Press.

Chernetsky, Vitaly. (2016). Ukrainian Queer Culture: The Difficult Birth. In Kārlis Verdin̄š and Jānis Ozoliņš (Eds.), Queer Stories of Europe (pp. 206-225). Newcastle upon Tyne: Cambridge Scholars Press.

Chick, Kay. (2008). Fostering an Appreciation for all Kinds of Families: Picturebooks with Gay and Lesbian Themes. Bookbird: A Journal of International Children's Literature, 46(1), 15-22.

Denysenko, Larysa, and Foya, Mariia. (2017). Majja ta i'i' mamy. Kyiv: Vydavnytstvo.

Edelman, Lee. (2004). No Future: Queer Theory and the Death Drive. Durham and London: Duke University Press.

Halperin, David. (1995). Saint Foucault: Toward a Gay Hagiography. Oxford: Oxford University Press.

Jackson, Stevie, and Jones, Jackie (Eds.). (1998). Contemporary Feminist Theories. Edinburgh: Edinburgh University Press.

Kachak, Tetyana. (2016). Ukrai'ns'ka literatura dlja ditej ta junactva: pidruchnyk. Kyiv: Akademija.

Kincaid, James. (1998). Erotic Innocence: The Culture of Child Molesting. Durham: Duke University Press.

Lesnik-Oberstein, Karín. (1994). Children's Literature: Criticism and the Fictional Child. Oxford: Oxford University Press.

Lewis, David. (2001). Reading Contemporary Picturebooks: Picturing Texts. New York and London: Routledge.

Lushchevska, Oksana. (2017, March 9). Majja ta i'i' mamy»: rozmai'ti modeli simej. Chytomo. Accessed January 3, 2019, from http://archive.chytomo.com/issued/majya-ta-iiii-mami-rozmaiiti-model i-simej/.

Martsenyuk, Tamara. (2012). The State of the LGBT Community and Homophobia in Ukraine. Problems of Post-Communism, 59(2), 51-62.

Miller, Jennifer. (2018). For the Little Queers: Imagining Queerness in "New" Queer Children's Literature. Journal of Homosexuality, https://doi.org/10.1080/00918369.2018.1514204. 
Morgan, Martin. (2017, September 15). Ukraine Far-Right Accused of 'Witch Hunt' over Children's Book. BBC News. Accessed January 3, 2019, from https://www.bbc.com/news/blogs-news-fromelsewhere-41282060.

Nikolajeva, Maria, and Scott, Carole. (2000). The Dynamics of Picturebook Communication. Children's Literature in Education, 31(4), 225-239.

Nikolajeva, Maria. (2014). The Penguin Looked Sad" Picturebooks, Empathy and Theory of Mind. In Bettina Kümmerling-Meibauer (Ed.), Picturebooks: Representation and Narration (pp. 121-138). London: Routledge.

Nodelman, Perry. (1998). Words About Pictures: The Narrative Art of Children's Picturebooks. Athens, GA: University of Georgia Press.

Pugh, Tison. (2011). Innocence, Heterosexuality, and the Queerness of Children's Literature. New York: Routledge.

Stella, Francesca. (2015). Lesbian Lives in Soviet and Post-Soviet Russia: Post-Socialism and Gendered Sexualities. Basingtstoke and New York: Palgrave Macmillan.

Stockton, Kathryn Bond. (2009). The Queer Child, or Growing Sideways in the Twentieth Century. Durham: Duke University Press.

Sunderland, Jane, and McGlashan, Mark. (2010). The Linguistic, Visual and Multimodal Representation of Two-Mum and Two-Dad Families in Children's Picturebooks. Language and Literature, 21(2), 189-210.

Świetlicki, Mateusz. (2018). “Oh, What a Waste of Army Dreamers...”: The Revolution of Dignity and War in Contemporary Ukrainian Picturebooks. Filoteknos, 8, 119-130.

Wesolowsky, Tony. (2017, September 14). In Ukraine, Children's Book Featuring Lesbian Parents Met with Threats, Fears of Violence. Radio Free Europe. Accessed January 3, 2019, from https://www. rferl.org/a/ukraine-childrens-book-lesbian-parents-threats-fear-lgbt-homophobia/28735738.html.

Zhuravel, Dmytro. (2017, October 10). Maya and Her Moms: To Criticize or To Read-This is the Question. OpinionUA. Accessed January 3, 2019, from https://opinionua.com/en/2017/10/10/maya-andher-moms-to-critifcize-or-to-read-this-is-the-question/.

ZIK. (2017, September 14). Dyskusija za uchasti Denysenko pro «skladni temy» na Forumi vydavciv projshla bez ekscesiv. Accessed January 3, 2019, from https://zik.ua/news/2017/09/14/dyskusiya_za_ uchasti_denysenko_pro_skladni_temy_na_forumi_vydavtsiv_proyshla_1167741/.

Publisher's Note Springer Nature remains neutral with regard to jurisdictional claims in published maps and institutional affiliations.

\section{Affiliations}

\section{Mateusz Świetlicki ${ }^{1}$}

Mateusz Świetlicki

mateusz.swietlicki@uwr.edu.pl

1 Institute of English Studies, University of Wrocław, ul. Kuźnicza 22, 50-138 Wrocław, Poland 